\title{
Changes in the Metabolite Profile during Micropropagation of Normal and Somaclonal Variants of Banana Musa AAA cv. Williams
}

\author{
Fredy P. Carrera ${ }^{1,2}{ }^{\mathbb{D}}$, Carlos Noceda ${ }^{3,4}$, María G. Maridueña-Zavala ${ }^{2} \mathbb{D}$, José A. García ${ }^{2}$, Omar Ruiz-Barzola ${ }^{5,6,7}$ (D) \\ and Juan M. Cevallos-Cevallos $2,5, * \mathbb{D}$
}

Citation: Carrera, F.P.; Noceda, C.; Maridueña-Zavala, M.G.; García, J.A.; Ruiz-Barzola, O.; Cevallos-Cevallos,

J.M. Changes in the Metabolite Profile during Micropropagation of Normal and Somaclonal Variants of Banana Musa AAA cv. Williams. Horticulturae 2021, 7, 39. https://doi.org/10.3390/ horticulturae7030039

Academic Editors: Douglas

D. Archbold and Sergio

Ruffo Roberto

Received: 26 January 2021

Accepted: 17 February 2021

Published: 26 February 2021

Publisher's Note: MDPI stays neutral with regard to jurisdictional claims in published maps and institutional affiliations.

Copyright: (C) 2021 by the authors Licensee MDPI, Basel, Switzerland. This article is an open access article distributed under the terms and conditions of the Creative Commons Attribution (CC BY) license (https:/ / creativecommons.org/licenses/by/ $4.0 /)$
1 Departamento de Ciencias de la Vida y la Agricultura, Carrera de Agropecuaria, Universidad de las Fuerzas Armadas ESPE, Santo Domingo P.O. Box 171-5-231B, Ecuador; fpcarrera@espe.edu.ec

2 Escuela Superior Politécnica del Litoral, ESPOL, Centro de Investigaciones Biotecnológicas del Ecuador CIBE, Campus Gustavo Galindo Km. 30.5 Vía Perimetral, Guayaquil P.O. Box 09-01-5863, Ecuador; gmaridue@espol.edu.ec (M.G.M.-Z.); jangarci@espol.edu.ec (J.A.G.)

3 Departamento de Ciencias de la Vida y de la Agricultura, Biología Celular y Molecular de Plantas (BIOCEMP)/Biotecnología Industrial, Universidad de las Fuerzas Armadas-ESPE, Av. General Rumiñahui s/n. Sangolquí, Santo Domingo P.O. Box 171-5-231B, Ecuador; cmnoceda@espe.edu.ec

4 Facultad de Ingeniería, Universidad Estatal de Milagro (UNEMI), Milagro, Guayas 091050, Ecuador

5 Escuela Superior Politécnica del Litoral, ESPOL, Facultad de Ciencias de la Vida, Campus Gustavo Galindo Km. 30.5 Vía Perimetral, Guayaquil P.O. Box 09-01-5863, Ecuador; oruiz@espol.edu.ec

6 Departamento de Estadística, Universidad de Salamanca, P.O. Box 37008 Salamanca, Spain

7 Escuela Superior Politécnica del Litoral, ESPOL, Centro de Estadística, Campus Gustavo Galindo Km. 30.5 Vía Perimetral, Guayaquil P.O. Box 09-01-5863, Ecuador

* Correspondence: jmceva@espol.edu.ec

Abstract: Micropropagation techniques allow the mass production of banana plants but can cause somaclonal variations such as dwarfism. Changes in the metabolite profile during micropropagation of normal (NP) and dwarf (DP) banana plants have not been described. Both, NPs and DPs of banana Musa AAA cv. Williams were micropropagated and the metabolite profile of vitroplants was assessed at the proliferation (PP), rooting (RP) and the second greenhouse-acclimatization (APII) phases of tissue culture. Metabolites from 10 DPs and 10 NPs meristems from each micropropagation phase were extracted and identified by gas chromatography coupled with mass spectrometry (GCMS). Principal component analysis (PCA) and test of statistical significance were applied to detect differentially accumulated metabolites. The PCA showed a clear grouping of DPs separated from NPs in RP and APII. Among the differentially accumulated metabolites, various precursors of apoplast components including arabinose and galactose or deoxygalactose in both PP and RP, as well as mannose and fucose in APII were under-accumulated in DPs. Results suggest affected apoplast composition during micropropagation of DPs.

Keywords: apoplast; in vitro culture; metabolomics; proliferation; rooting; acclimatization

\section{Introduction}

Banana (Musa spp.) is an essential crop from socioeconomic and ecological perspectives [1]. The world production of banana fruits was 119,191.0 million tons in 2018 and Ecuador was the top exporter with a production of 6,505,000 tons (FAO, 2019). Cavendish is the most cultivated banana subgroup in the world, representing more than $40 \%$ of the global production and more than $15 \%$ of the exports [2].

In vitro propagation is an effective tool for production $[3,4]$, conservation and use of plants [5]. Banana micropropagation consist of an in vitro cell proliferation phase (PP) followed by an in vitro rooting phase (RP) and two greenhouse acclimatization phases (API and APII). However, growth conditions and material management during the in vitro phases can cause chromosomal rearrangements, loss or duplication of DNA fragments, 
small mutations, and DNA methylation [6] that can yield the phenotypic changes known as somaclonal variation (SV) [7]. In a broad sense SV encompasses inheritable phenotypic and genotypic variability $[8,9]$ affecting up to $88 \%$ of banana plants produced in vitro $[6,10]$. Among all the SVs, dwarfism is the most common in Musa spp., affecting up to $80 \%$ of the micropropagated banana plants [11].

The type and frequency of SVs depend on the genotype of the starting material used for micropropagation. The Musa genus shows a great plurality with various levels of ploidy and genetic makeup. Therefore, diploid (AA, BB, AB), triploid (AAA, AAB, $\mathrm{BBB}$ ) and tetraploid (AAAA, AAAB) Musa genotypes [12-14] have been reported. The commercial Cavendish banana subgroup possesses a triploid AAA genome shown to be more unstable during in vitro propagations than the AAB and ABB subgroups [11,15]. Therefore, Cavendish bananas have shown a high susceptibility to various SVs, including dwarfism which represents up to $90 \%$ of the SV in this subgroup [8]. Despite the importance of SV to the banana industry, the underlying causes of dwarfism are not fully understood.

Phenotypically, dwarf banana plants show a short height, small distance between petioles, short petiole length and low leaf index. Additionally, banana bunches and fingers from dwarf plants are smaller than those from true-to-type (normal) individuals [8]. Identification of SV before the plant reach the field can avoid economical loses. However, the recognition of phenotypic characteristics and diagnosis of dwarfism can only be achieved by trained personnel at the end of the greenhouse acclimatization phase or in the field [8]. Molecular techniques such as random amplified polymorphic DNA (RAPD) $[7,16-18]$ amplified fragment length polymorphisms (AFLPs) [19] and inter simple sequence repeats (ISSRs) [17,20-23] have been proposed to monitor SV in Musa. However, the relationship among the proposed molecular markers and the SVs was not described.

In general, metabolites have been more closely associated with phenotypes than genes, and metabolomics has been proposed as the link between genotypes and phenotypes [24]. Metabolomic techniques have been used to assess plant responses to biotic and abiotic stresses as well as other treatments [25-29] while gaining insights into the physiological and biochemical state of the plants under given conditions [27,30,31]. Gas chromatography coupled with mass spectrometry (GC-MS) is the most used analytical technology for metabolite profiling [30] and has allowed the diagnosis of dwarf SV in banana plants at the greenhouse phase [32]. However, metabolite changes occurring during the early stages of in vitro culture of banana plants, including PP and RP, as well as the greenhouse APII have not been reported.

The present research aimed to characterize the metabolite profile of normal and dwarf banana plants (Musa AAA subgroup Cavendish cv. Williams) during PP, RP and APII.

\section{Materials and Methods}

\subsection{Plant Material}

Meristems from Musa (AAA) Cavendish subgroup cv. Williams were obtained from two 5-year-old plantations showing genetic homogeneity and located around Guayaquil City (Ecuador). Two normal mother plants (M1 and M2) from plantation 1 were selected as the starting material for the assessment of the proliferation and rooting micropropagation phases whereas several normal mother plants from plantation 2 were used for the analysis of the acclimatization phase. The normal plants were true-to-type (with no signs of deformations or somaclonal variations) and showed no symptoms of diseases. For both plantations, apical tips from each plant were submitted to a clonal in vitro culture process that included 6 proliferation subcultures, followed by one rooting and two acclimatization phases carried out in Sociedad Ecuatoriana de Biotecnología de la ESPOL (SEBIOCA) and CIBE facilities at ESPOL University in Guayaquil as described in Section 2.2.

For plantation 1, selected plants at the end of APII were transferred to the field to allow the growth of suckers (plants developed from the roots of a parent plant) until they could be readily identified as DP or NP (approximately one year). One NP and one DP sucker plant from M1 (and from the same 6th subculture vitroplant) as well as one DP sucker plant 
from M2 were then selected for further propagation. The selected sucker plants showed the same NP or DP phenotype as the corresponding field vitroplant they were attached to. Apical tips from the selected sucker plants were submitted to the micropropagation process described in Section 2.2. with only 3 proliferation subcultures at PP prior to RP and the two acclimatization phases. Random samples from PP and RP were submitted to the metabolite profiling protocol described in Section 2.4, whereas samples from APII were used for phenotype assessment as described in Section 2.3.

For plantation 2, plants at the end of APII were classified as NP or DP as described in Section 2.3. (see Supplementary Figures) and random samples were submitted to the metabolite profiling protocol described in Section 2.4. Figure 1 shows the process followed for obtaining the plant materials. The Supplementary figures show pictures of the samples at each micropropagation stage.

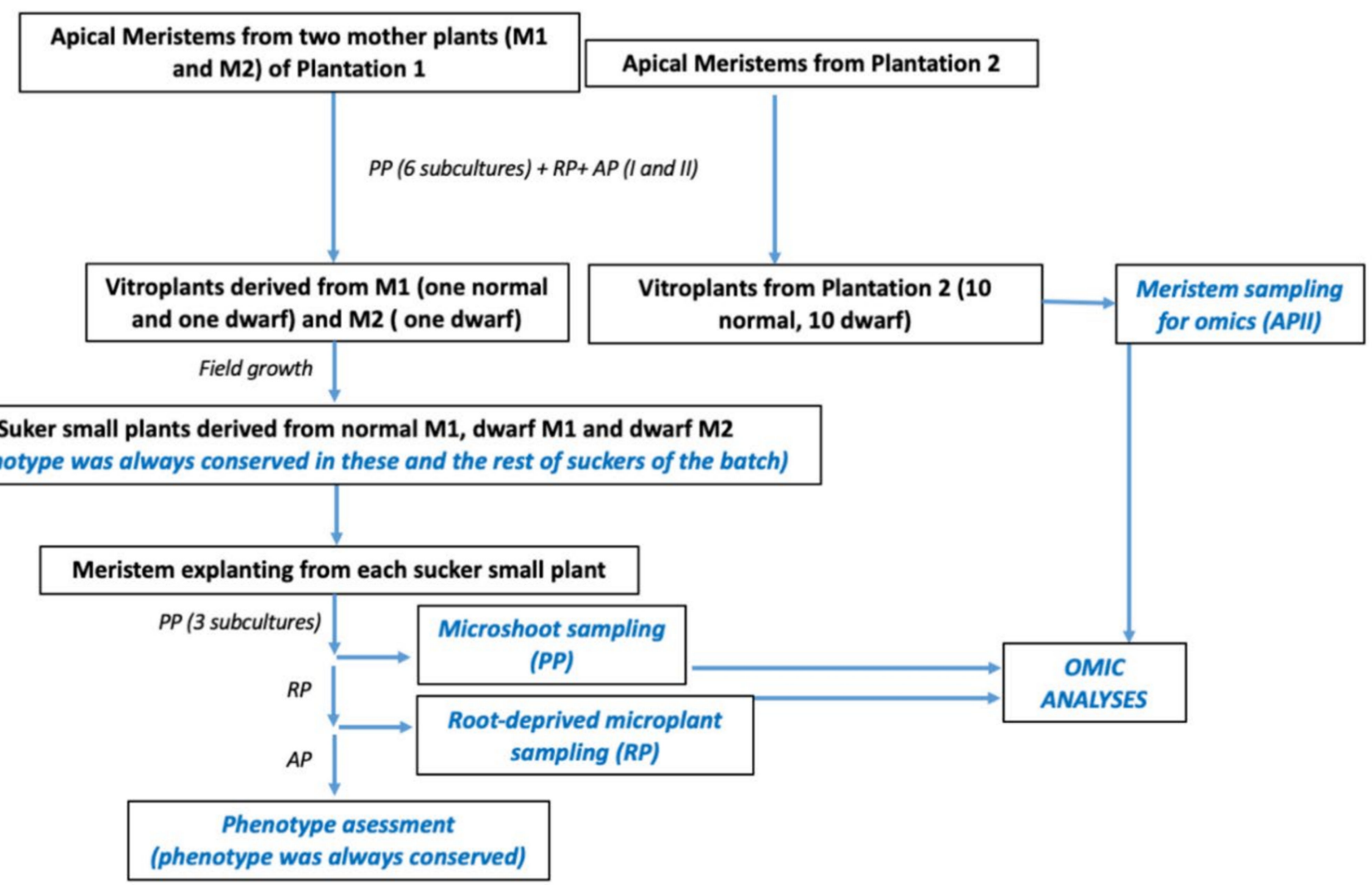

Figure 1. Plant micropropagation scheme.

\subsection{In Vitro Establishment of Banana Plants}

All the apical and sucker tips collected were washed with water and reduced to a size of $3 \mathrm{~cm}$ high $\times 3 \mathrm{~cm}$ diameter. The reduced tips were then immersed in a $2 \%$ chlorine solution for $20 \mathrm{~min}$ and rinsed by immersion in sterile water for $2 \mathrm{~min}$. The 2-min rinsing step was repeated 4 times using fresh sterile water each time. Meristems were obtained by further reducing the tips to $1.5 \mathrm{~cm}$ height $\times 1.5 \mathrm{~cm}$ base diameter. The obtained meristematic domes were placed onto a media composed of MS [33], salts and vitamins, $1.25 \mathrm{mg} / \mathrm{L}$ kinetin, $4.0 \mathrm{mg} / \mathrm{L}$-benzylaminopurine, $3.0 \mathrm{~g} / \mathrm{L}$ sucrose and $2.0 \mathrm{~g} / \mathrm{L}$ phytagel and incubated at $22-25^{\circ} \mathrm{C}$ for one month with 12 -h photoperiods generated by white light fluorescent tubes yielding a photosynthetic light radiation of $50 \mu \mathrm{mol} \mathrm{m}^{-2} \mathrm{~s}^{-1}$ [34].

Meristematic domes were then submitted to a PP. For this, the domes were divided into two halves and each half was placed onto the same MS-based culture medium described above. The propagules were then divided and subcultured onto fresh media every 30 days. A total of six subcultures were obtained from meristems of both plantations. 
Since sucker plants from plantation 1 underwent a second micropropagation cycle, only three proliferation subcultures were performed until sufficient plant material for analysis was obtained.

The microshoots obtained from the final subculture entered the RP. For this, the microshots were rooted in flasks with MS [33] semisolid medium supplemented with $1.25 \mathrm{mg} / \mathrm{L}$ kinetin, $0.52 \mathrm{mg} / \mathrm{L}$ 3-indoleacetic acid, $30 \mathrm{~g} / \mathrm{L}$ sucrose and $2 \mathrm{~g} / \mathrm{L}$ phytagel. After a 30-day period at $22-25{ }^{\circ} \mathrm{C}$ with 12 -h photoperiods, vitroplants were removed from the flasks and placed under tap water to wash out agar residues.

Cleaned rooted plants were then submitted to API and APII. For this, plants were placed into plastic trays with sterile moss peat BERGER (BM2) and grown in greenhouse at $24-35^{\circ} \mathrm{C}, 75-95 \%$ humidity and $12 \mathrm{~h}$ photoperiod of natural light (API). After 4 weeks, the plants were transferred to new containers with a mixture of sand, rice paddy and clay (1:2:2), and grown in the greenhouse under the same conditions as API (APII) for 24 weeks until a minimum size of about $50 \mathrm{~cm}$ height was reached (see Supplementary Figures).

\subsection{Phenotype Analysis}

The phenotype of all regenerants was analyzed at the end of APII. As all plants at APII were the same age, plants were classified as DP or NP by inspecting their height, distance between petioles, petiole length and leaf index. In general, all plants that at the end of APII were at least $10 \mathrm{~cm}$ shorter and possessed more rounded leaves than the average NP were classified as DP.

\subsection{Metabolite Profiling}

Random samples from PP, RP and APII were taken for metabolomic analysis. Each sample from PP and RP consisted of a pool of two microshots or root-deprived vitroplants from plantation 1, respectively. Each pool contained $0.7 \mathrm{~g}$ of the individual samples. A total of 30 pools were analyzed at each PP and RP as follows: 10 pools from normal plants (NP1-NP10) and 10 pools from dwarf plants (DP1-DP10) originating from M1 as well as additional 10 pools from dwarf vitroplants (DP11-DP20) originating from M2. APII samples consisted of individual apical meristems from 10 normal (NP1-NP10) and $10 \mathrm{dwarf}$ (DP1-DP10) plants originating from plantation 2.

The metabolite extraction, detection and identification were carried out as suggested by Cevallos-Cevallos et al. [32]. Briefly, samples were frozen at $-80^{\circ} \mathrm{C}$ prior to grinding to a fine powder under liquid nitrogen. About $0.3 \mathrm{~g}$ of the powder was placed in an Eppendorf tube and $1 \mathrm{~mL}$ of methanol/chloroform/water solution was added to each powder in an 8:1:1 ratio and mixed. Samples were then incubated at $7^{\circ} \mathrm{C}$ for $48 \mathrm{~h}$ and centrifuged at $15,000 \mathrm{rpm}$ for $2 \mathrm{~min}$. About $650 \mu \mathrm{L}$ of the supernatant was placed in a water bath at $80^{\circ} \mathrm{C}$ until dry as suggested in previous studies [35], and the metabolites were re-suspended in $150 \mu \mathrm{L}$ of N-methyl-N-trimethylsilyltrifluoroacetamide (MSTFA) and incubated during $90 \mathrm{~min}$ at $80{ }^{\circ} \mathrm{C}$. The suspension was then transferred to $500 \mu \mathrm{L}$ inserts placed in $2 \mathrm{~mL}$ chromatographic vials and analyzed in a GC-MS (7890A GC system and 5975C inert XL MSD, Agilent Technologies), with a DB-5MS capillary column $(30 \mathrm{~m} \times 0.25 \mathrm{~mm})$ of phenyl methylpolysiloxane $(0.25 \mu \mathrm{m}$ film thickness) as stationary phase. The injector temperature was $250^{\circ} \mathrm{C}$, the initial oven temperature was maintained at $80^{\circ} \mathrm{C}$ for $1 \mathrm{~min}$, the temperature gradient was $7{ }^{\circ} \mathrm{C} / \mathrm{min}$ and the final temperature was $300^{\circ} \mathrm{C}$ that was maintained for $5 \mathrm{~min}$. Ultra-pure helium was used as carrier gas at $1 \mathrm{~mL} / \mathrm{min}$. The GC-MS interface was set at $280^{\circ} \mathrm{C}$ and the scan was recorded at a frequency of $4 \mathrm{~Hz}$. The data were obtained using ChemStation E.02.02 software (Agilent Technologies, Santa Clara, CA, USA) and differentially accumulated metabolites were identified by matching their MS spectra using both the mass spectometer database of the National Institute of Standards and Technology (NIST) Library (NIST 11) and the Wiley Registry of mass spectral database (9th edition, Wiley 9) (McLafferty 2009). The metabolite identity was confirmed by comparing the linear retention rate of each compound with that of the pure standard using our internal database. All metabolites were quantified by estimating their individual peak area [32,35]. 


\subsection{Data Analysis}

This study followed an observational-descriptive design to assess the metabolite profile of DPs and NPs. The metabolite levels were normalized to the total area prior to alignment using the MZmine2 software [36] and the metabolite profile of DPs and NPs was compared using both multivariate and univariate statistical methods. For PP and RP, 10 replicates of each DP from M1 and M2, as well as 10 replicates from NP were used. As for APII, 9 replicates from each DP and NP were used for both multivariate and univariate comparisons.

For multivariate comparisons, principal components analysis (PCA) was carried out using XLSTAT 2019 (Addinsoft, Boston, MA, USA) on NP and DP samples originating from M1 at PP and RP whereas DP samples from M2 were included as an assessment set after PCA calculations at both phases. All NP and DP samples from APII were used for PCA.

After verifying that the data were not normal-distributed, the non-parametric U MannWhitney test was used for univariate comparisons to determine the differentially expressed metabolites, at a significance level of 0.05 , between DPs and NPs from M1 at the PP and $\mathrm{RP}$, respectively as well as all the DP and NP samples at the APII. Significant differences between the metabolite levels of DPs from M2 and NPs were also assessed.

\section{Results}

\subsection{Phenotype Heritability}

All the 3rd-subculture regenerants derived from plantation 1 showed the same phenotype of the mother field-vitroplant at APII. For M1, 13 dwarf and one undefined plant were obtained from the dwarf mother field vitroplant whereas 12 normal and 2 undefined plants were obtained from the normal mother field vitroplant. For M2, all the regenerants were DPs as was the mother field vitroplant.

\subsection{Overall Metabolite Profiling}

A total of 55, 27 and 40 metabolites were detected in PP, RP and APII, respectively. The PCA run using samples from PP, showed no obvious grouping of NPs and DPs from M1 but a clear separation of DPs from M2 along PC2 was evidenced. Additionally, DPs from M1 were more dispersed along both axes than NPs (Figure 2A). PC1 contributed to $20.94 \%$ of the overall variance, whereas PC2 contributed to $16.18 \%$. The metabolites with the highest absolute loading values in PC1 were methyl- $\alpha$-D-Galactopyranoside, 2-keto-D-gluconic acid, 2-pentenidioic acid, altronic acid, D-ribofuranose, D-Glucose 2-amino-2-deoxy and 2,3,4,5-Tetrahydroxypentanoic acid, D-Ribofuranose and D-Glucose, whereas PC2 showed high absolute values of methyl- $\alpha$-D-Glucopyranoside, $B$-D-Galactofuranose, D-glucuronic acid and sebacic acid, L-(-) Sorbose, L-Glutamine, $\beta$-L-Arabinopyranose, linolenic acid, gluconic acid, propanoic acid, L-methionine and Phenylalanine (Figure 2B).

The PCA run using M1 samples from RP showed a clear grouping of NPs separated from DPs along PC2. A more notorious separation of DPs from M2 was also observed along both PCs (Figure 3A). PC1 contributed to $21.70 \%$ of the overall variance whereas PC2 contributed to $17.17 \%$. The metabolites with the lowest PC2 loadings (more abundant in DPs than in NPs) were 1,2,3-Propanetricarboxylic acid 2-hydroxi, 2-Keto-d-gluconic acid, Psicofuranose and Propanoic acid, whereas D-Galactose 2-deoxy, D-Fructose, D(-)-Fructofuranose and $\beta$-L-Arabinopyranose showed the highest PC2 loadings (more abundant in NPs compared to DPs) (Figure 3B). 
Table 1. Differentially accumulated metabolites in dwarf plants (DF) when compared with normal plants (NP) $(p<0.05)$.

\begin{tabular}{|c|c|c|c|c|}
\hline No. & METABOLITE & CLASS & $\log _{2}$ FC M1DP-M1NP & $\log _{2}$ FC M2DP-M1NP \\
\hline \multicolumn{5}{|c|}{ Proliferation Phase } \\
\hline 1 & Sebacic acid & Dicarboxylic acid & 3.520 & n.s. \\
\hline 2 & $\begin{array}{l}\text { 2,3,4,5-Tetrahydroxypentanoic } \\
\text { acid-1,4-lactone }\end{array}$ & Carboxylic acid & 2.304 & n.s. \\
\hline 3 & D-Ribofuranose & Monosaccharide & 2.226 & n.s. \\
\hline 4 & D-Glucose & Monosaccharide & -0.995 & n.s. \\
\hline 5 & L-(-)-Sorbose & Monosaccharide & -0.908 & n.s. \\
\hline 6 & $\beta$-L-Arabinopyranose & Monosaccharide & -0.918 & -6.252 \\
\hline 7 & $\alpha$-D-Galactopyranose & Monosaccharide & -1.479 & -1.013 \\
\hline 8 & Phenylalanine & Aminoacid & UDP & n.s. \\
\hline \multicolumn{5}{|c|}{ Rooting Phase } \\
\hline 9 & Propanoic acid & Carboxilic acid & 3.666 & NS \\
\hline 10 & 2-Keto-D-gluconic acid & Carboxilic acid & 2.694 & 1.898 \\
\hline 11 & $\begin{array}{c}\text { 1,2,3-Propanetricarboxylic acid, } \\
\text { 2-hydroxi (Citric acid) }\end{array}$ & Tricarboxylic acid & 0.954 & 0.944 \\
\hline 12 & D-Psicofuranose & Monosaccharide & 0.907 & UDP \\
\hline 13 & D-Galactose, 2-deoxy & Monosaccharide & -1.084 & -0.620 \\
\hline 14 & D-Fructose & Monosaccharide & -1.076 & -1.510 \\
\hline 15 & D-(-)-Fructofuranose & Monosaccharide & -1.246 & NS \\
\hline 6 & $\beta$-L-Arabinopyranose & Monosaccharide & -1.264 & UDP \\
\hline \multicolumn{5}{|c|}{ Acclimatization Phase II } \\
\hline 16 & $\beta$-D-Galactofuranose & Monosaccharide & UNP & n.a. \\
\hline 17 & Gulonic acid & Carboxilic acid & UNP & n.a. \\
\hline 18 & D-(+)-Galacturonic acid & Monosaccharide & 2.852 & n.a. \\
\hline 19 & N-Acetyl glucosamine & Amino sugar & -0.755 & n.a. \\
\hline 20 & $\begin{array}{l}\text { D-Galactose, 2-amino-2-deoxy } \\
\text { (D-Galactosamine) }\end{array}$ & Amino sugar & -0.969 & n.a. \\
\hline 21 & Mannose & Monosaccharide & -2.307 & n.a. \\
\hline 22 & $\begin{array}{l}\text { L-6 deoxy-Galactopyranose } \\
\text { (L-Fucopyranose) }\end{array}$ & Monosaccharide & -3.993 & n.a. \\
\hline 23 & L-Glutamine & Aminoacid & UDP & n.a. \\
\hline 24 & $\alpha$-D-Glucopyranoside, methyl & Monosaccharid & UDP & n.a. \\
\hline 25 & Uridine & Nucleoside & UDP & n.a. \\
\hline
\end{tabular}
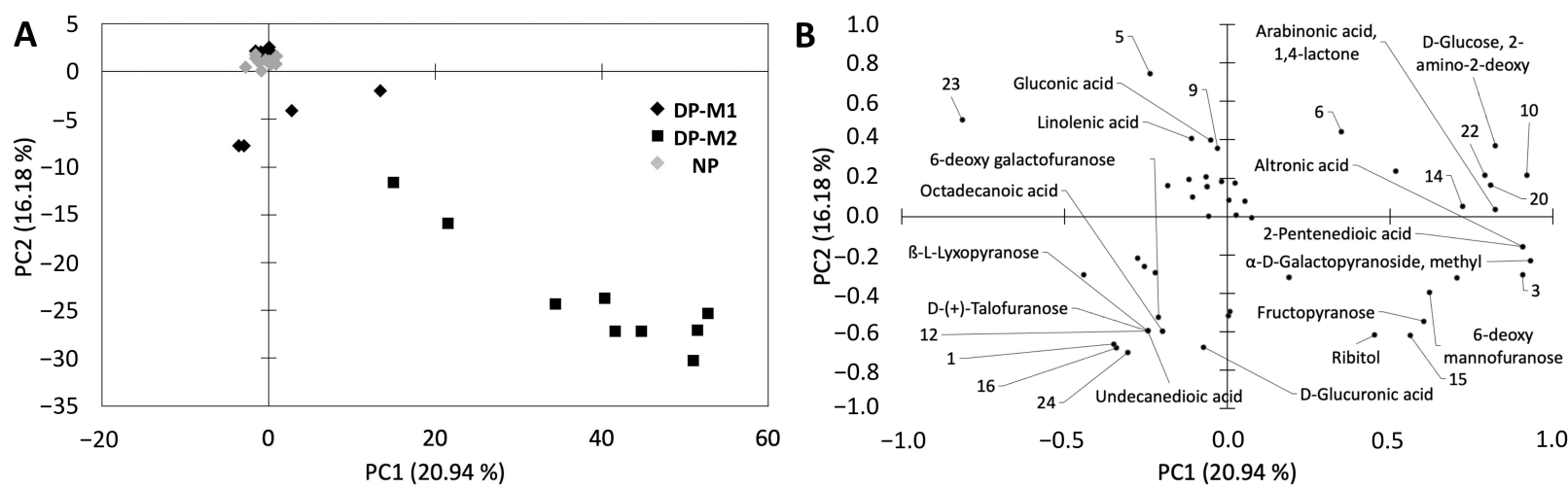

Figure 2. PCA score (A) and loading (B) plots of the metabolite profile from Musa AAA cv. Williams samples at the proliferation phase (end of 3rd subculture) coming from meristem M1 (N1-N10: normal plants, D1-D10: dwarf plants), for which the PCA was performed. Additionally, the plants M2 DP (11-19) are also visualized as an assessment set. Metabolites numbers in the loading plot correspond to Table 1. 

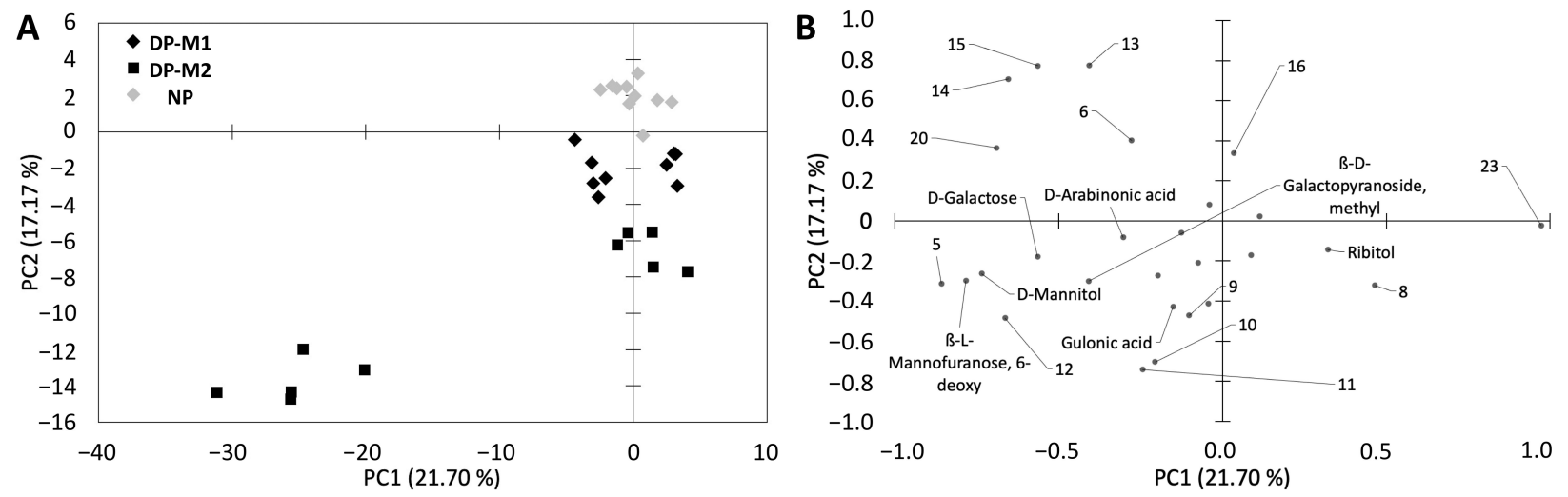

Figure 3. PCA score (A) and loading (B) plots of the metabolite profile of root-deprived Musa AAA cv. Williams microplants at the Rooting Phase coming from meristem M1 (N1-N10: normal plants, D1-D10: dwarf plants), for which the PCA was performed. Additionally, the plants M2 DP (11-19) are also visualized as an assessment set. Metabolites numbers in the loading plot correspond to Table 1.

The PCA run using APII samples showed a clear grouping of NPs and DPs on both PC1 and PC2 (Figure 4A). PC1 contributed to $19.66 \%$ of the variability while PC2 contributed to $15.16 \%$. The loading plot showed that the metabolites in the upper-right quadrant such as $\beta$-D-Galactofuranose and D-(+)-Galacturonic acid were more abundant in DPs when compared to NPs, whereas the metabolites in the bottom-right quadrant including, L-Galactopyranose 6 deoxy, methyl- $\alpha$-D-Glucopyranoside, Uridine, $\alpha$-D-Galactopyranose, aspartic acid, 2-amino-2-deoxy-D-galactose, L-Glutamine, N-acetylglucosamine and 2amino-2-deoxy D-Galactose were more abundant in NPs compared to DPs (Figure 4B).
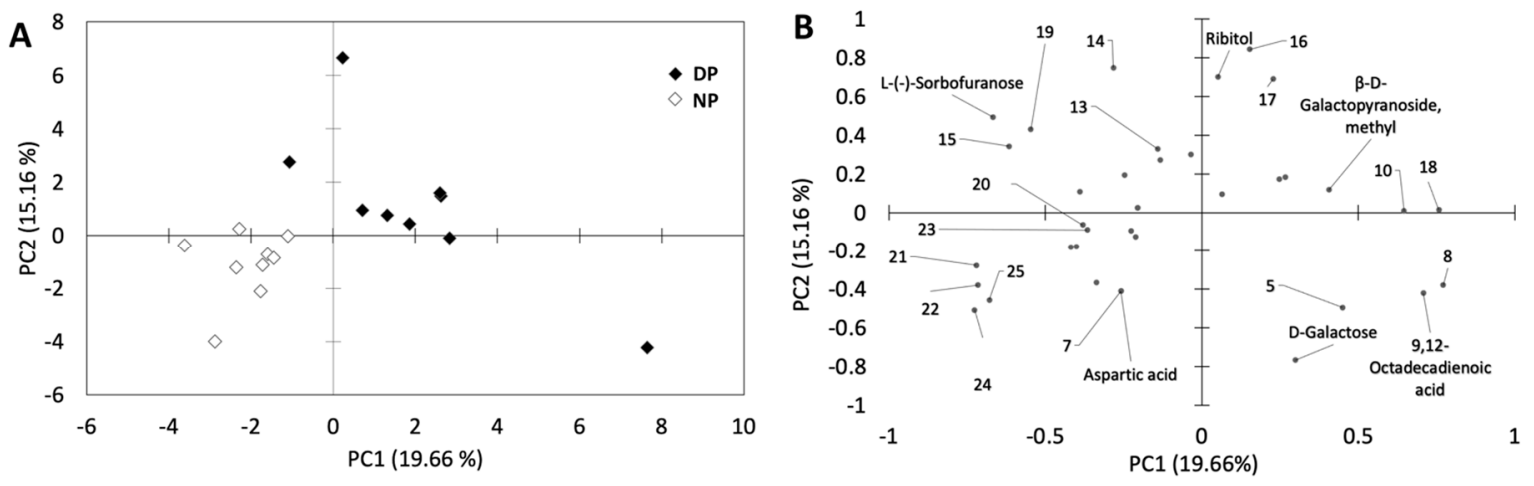

Figure 4. PCA score (A) and loading (B) plots of the metabolite profile from Musa AAA cv. Williams plants in the Acclimatization Phase II. $\mathrm{N}=$ normal plants $\mathrm{D}=$ dwarf plants. Metabolites numbers in the loading plot correspond to Table 1.

\subsection{Individual Metabolites}

The U Mann-Whitney test run to compare DP and NP from M1 at PP revealed that the levels of two carboxylic acids including sebacic acid and 2,3,4,5-Tetrahydroxypentanoic acid-1,4-lactone, as well as D-ribofuranose, were significantly higher in DPs when compared to NPs, whereas the levels of the monosaccharides D-Glucose, L-(-)-Sorbose, $\beta$-LArabinopyranose and $\alpha$-D-Galactopyranose were significantly reduced in DPs (Table 1 ). Similarly, the aminoacid Phenylalanine was only detected in NPs. When the MannWhitney U test was run to compare DP from M2 versus NP from M1, two monosaccharides ( $\beta$-L-Arabinopyranose and $\alpha$-D-Galactopyranose) were also less abundant in DPs than in NPs (Table 1).

In the RP, the Mann-Whitney U test used to compare DPs and NPs from M1 showed that the levels of organic acids such as Propanoic, 2-Keto-d-gluconic and 1,2,3Propanetricarboxylic acid as well as D-Psicofuranose, were significantly higher in DPs 
than in NPs, whereas the levels of the aldohexoses D-Fructose (including the form D-(-)Fructofuranose) and 2-deoxy-D-Galactose as well as $\beta$-L-Arabinopyranose were significantly reduced in DPs (Table 1). The comparison between M2 DPs and M1 NPs also showed a significant increase in the levels of 2 keto-d-gluconic acid and 1,2,3-propanetricarboxylic acid 2-hydroxi in DPs in M2 DPs but D-Psicofuranose was not detected in this sample group. Similarly, the levels of 2-deoxy-D-galactose, D-Fructose and $\beta$-L-Arabinopyranose were reduced in DPs from M2 (Table 1).

Similarly, the Mann-Whitney U test run at APII showed that galacturonic acid was overproduced in DPs whereas the levels of N-Acetyl glucosamine, D-Galactose, 2amino-2-deoxy, Mannose and L-Fucopyranose were significantly reduced in DPs. Similarly, $\beta$-D-Galactofuranose and gulonic acid were only detected in DPs while methyl- $\alpha$-Dglucopyranoside, uridine, and L-glutamine were only detected in NPs (Table 1).

\section{Discussion}

\subsection{Phenotype Analysis}

As dwarfism can only be diagnosed in APII or in field plants, it is not possible to select dwarf phenotypes for analysis during the early in vitro phases of micropropagation. In this study, the phenotype of the field regenerant was always conserved by their small sucker plants. Therefore, microplants obtained from previously identified adult dwarf variants were considered as DPs at the in vitro micropropagation stages. The heritability of the phenotype was verified in the greenhouse phases, as plants in APII showed the same phenotype as their respective mother plant (see Supplementary Figures). Results suggests that various biochemical processes associated to the somaclonal variability of the plants were maintained during the micropropagation phases. In this study, differential accumulation of various metabolites was observed when comparing DPs and NPs at each micropropagation stage, suggesting a possible relationship between metabolites and phenotype, even before the plant morphology became apparent.

\subsection{Overall Metabolite Profile}

A total of 119 metabolites were detected in the microshoots and meristems from PP, RP and APII. A higher number of metabolites have been reported in APII banana leaves [32]. The data suggest a higher metabolic activity in banana leaves when compared to meristems or microshoots. However, as leaves are not produced at the early stages of micropropagation, meristems and meristem-derived microshoots were used in this study. Despite the low number of metabolites observed, results showed that the metabolite profile of meristems and microshoots can also be used to characterize SVs in banana plants.

The PCAs were able to clearly differentiate DPs from NPs in RP and APII, with clusters becoming more separated as the plant production phases progressed. This observation suggests that various biochemical functions were differentially activated in DPs as the vitroplants developed. In the PP, no grouping of DPs and NPs was observed but DPs were more dispersed along the score plot than NPs, indicating a high metabolic variability in proliferating DPs. However, DPs from M2 grouped separately from the rest of the samples in both PP and RP, suggesting that the selection of the mother plant affected the metabolite profile of the produced plantlets.

The differentially accumulated metabolites were carboxylic acids, monosaccharides, amino acids and amino sugars as well as one nucleoside (Table 1). In the three micropropagation phases studied, all the differentially accumulated carboxylic acids were most abundant in DPs, whereas the majority of the differentially accumulated monosaccharides as well as all of the amino acids and the nucleoside were most abundant in NPs.

\subsection{Differentially Accumulated Carboxylic Acids}

Accumulation of organic acids has been observed in plants with mineral deficiencies [37], and the high amounts of this metabolite group suggest a mineral unbalance in DPs specially in the in vitro phases. Among the differentially accumulated carboxylic acids, 
DPs from PP showed higher levels of 2,3,4,5-Tetrahydroxypentanoic acid-1,4-lactone and sebacic acid than NPs. The 2,3,4,5-Tetrahydroxypentanoic acid has several stereoisomers but the one reported in plants is xylono-1,4-lactone [38,39]. Stereoisomers are not usually differentiated in untargeted metabolomic analysis and generally require additional chiral separations. Xylono-1,4-lactone is naturally produced in plants by dehydrogenation of xylose-a monomer of pectin and hemicellulose-by microorganisms [40]. Thus, the high levels of the putative xylonolactone in DPs suggest xylose oxidation and an affectation to the cell wall. Similarly, sebacic acid is usually derived from the oxidation of longer dicarboxylic acids in mammals [41]. In plants, long dicarboxylic acids are part of suberin, which confers protection in cell walls. Therefore, the high levels of both xylonolactone and sebacic acid suggest oxidation of cell wall component precursors in DPs, potentially caused by the oxidative stress commonly observed during micropropagation [42]. Results suggest a differential response to oxidative stress in DPs. Further research is needed to assess the role of sebacic acid in plant development and SV. Additionally, in the aerial part of vitroplants from the RP, citric and 2-keto-D-gluconic carboxylic acids over-accumulated in all DPs regardless of the mother plant, suggesting both metabolites as potential biomarkers of dwarfism in this phase.

\subsection{Differentially Accumulated Monosaccharides and Plant Cell Wall Components}

Among the differentially accumulated monosaccharides, only D-ribofuranose-the furanose form of ribose- and D-psicose in the form of D-psicofuranose were significantly accumulated in DPs from PP and RP, respectively. The accumulation of both sugars has been associated with deficient plant development and ribose accumulation has been linked to inhibited plant growth caused by the absence of plant ribokinases [43]. Further research is needed to assess the ribokinase activity in DPs. Similarly, D-psicose can induce plant resistance to stress [44], which can also generate SV [45]. Furthermore, psicose can inhibit various enzymes related to the hydrolysis of higher saccharides [46] and has been associated with plant growth [44].

In all the studied phases, several precursors or monomers of apoplast (cell wall and middle lamella) polysaccharides (hemicelluloses and pectin) were under-accumulated in DPs. In PP, the hemicelluloses and pectin monomers glucose, sorbose, arabinopyranose and galactopyranose were under-accumulated in DPs. In plants, glucose can act as a signaling molecule to stimulate plant growth and changes in the levels of this monosaccharide have been shown to affect plant development [47]. Similarly, D-Glucose is the sole monomer of the cellulose present in the plant's cell wall and the low levels of this monosaccharide suggest a decreased synthesis of cellulose and a misconstruction of the cell wall. Additionally, glucose is commonly in charge of the transport of monolignols derived from phenylalanine-also under-accumulated in DPs from PP-via phenylpropanoids, to build lignin in the apoplast [48]. Therefore, the low levels of both glucose and phenylalanine in DPs suggest a reduced lignin content in the apoplast.

In the PP, the aldoses galactose and arabinose in the form of $\alpha$-D-Galactopyranose and $\beta$-L-Arabinopyranose, respectively, were at reduced levels in DPs regardless of the mother plant and can be proposed as biomarkers for DPs in this phase. The cycled forms pyranose or furanose can be formed randomly from the original monosaccharide during the sample preparation for metabolomic analysis [49]. Both galactose and arabinose are monomers of the apoplast polysaccharides hemicellulose and pectin $[50,51]$ and the low levels of these metabolites suggest a missconstruction of the apoplast in DPs. Similarly, $\beta$-L-Arabinopyranose, 2-deoxy-D-galactose and fructose were also under-accumulated in DPs from both M1 and M2 in the RP, showing the potential of these metabolites as biomarkers of banana dwarfism in the RP. Moreover, the data suggest L-Arabinose as potential biomarker for DPs in both PP and RP. Deficiencies in other apoplast components, including the hemicellulose precursors mannose and fucose [50,52], were observed in DP meristems from APII. 
Furthermore, Uridine was not detected in DPs from APII. Uridine is typically involved in glucidic metabolism and glucose-uridin biphosphate contributes to saccharose biosynthesis, respiration and energy supply in the plant by transferring glucose to fructose in photosynthetic cells [53]. This nucleotide also supports monosaccharide provision to various plant components, including the apoplast $[54,55]$. The absence of uridine in DPs suggests a low energy provision and probably contributed to a reduced biosynthesis of apoplast components in this sample group.

Although hemicellulose components were under-accumulated in DPs from APII, the pectin components $\beta$-D-Galactose and D-galacturonic acid, were more abundant in DPs than in NPs in this phase, suggesting alterations in the pectin structure of this sample group. Changes in pectin structure can influence the growth, final size and robustness of plant tissues [56]. Results are in agreement with previous reports showing that other hemicellulose and pectin component (rhamnose) can over-accumulate in DP leaves at the APII potentially contributing to the thick pseudostem observed in this sample group [32].

Altogether, the data suggest a misconstruction of the apoplast in DPs at each phase of the micropropagation. Construction of cell wall is critical for plant cell growth [57], and an incomplete formation of cell wall components has been associated to SV after micropropagation by protoplast cultures [58]. The observed alterations in the apoplast constitution probably affected cell shaping [59] and contributed to the development of the phenotypic characteristics observed in the DP phenotype. Consequently, a putative relationship between the apoplast structure and different morphological traits of dwarf phenotypes was observed in this study.

\subsection{Differentially Accumulated Aminated Metabolites}

The amino acids phenylalanine and glutamine were absent in DPs from PP and APII, respectively. Phenylalanine can produce phenylpropanoids to cooperate in all aspects of plant responses to biotic and abiotic factors [60] and favor adaptation to new habitats [61], including those applied during in vitro culture. The absence of this amino acid in DPs suggests a reduced response to the oxidative stress caused by the micropropagation and probably contributed to the limited growth observed in DPs, as abiotic stresses can limit plant development [62]. Similarly, glutamine usually acts as an intermediary of nitrogen assimilation reactions in plants [63]. Nitrogen assimilation is associated with plant development and the absence of glutamine might have contributed to the limited growth observed in DPs.

D-galactosamine and $\mathrm{N}$-acetylglucosamine have been found in proteins associated with the plant cell wall $[64,65]$, as well as in microbial cell wall [66-68]. Both metabolites were not differentially accumulated in PP and RP. Therefore, the differential accumulation of both aminated monosaccharides exclusively in APII may be associated with the presence of plant fungi in this non-sterile phase. The low levels of both metabolites in DPs from APII suggest a differential response to microorganisms in this sample group.

In the present work, we reported differentially accumulated metabolites commonly associated with oxidative stress and / or plant cell wall biosynthesis as well as aminated sugars usually generated from the degradation of fungal cell walls. Results correlate with previous reports showing alterations in genes associated to glucose synthesis, galactose transference and lignin formation in field and in vitro grown Musa spp. [69]. Further research is needed to assess all the DPs physiological associations with the plant's metabolite profile.

\section{Conclusions}

The present work showed differentially accumulated metabolites between both studied phenotypes suggesting a differential response to oxidative processes and disruption of the biosynthesis of apoplast components in DPs. Thus, low levels of arabinose, a component of several polysaccharides in both plant cell wall and middle lamella, characterize dwarf phenotype in the in vitro phases. The observed alterations can affect cell shape and contribute to the macromorphologic characteristics observed in dwarf phenotypes. 
This is the first report showing the changes in the metabolite profile occurring during micropropagation of normal and somaclonal plant variants.

Supplementary Materials: The following are available online at https:/ / www.mdpi.com/2311-7 524/7/3/39/s1, Figure S1: Representative banana samples at the proliferation phase, Figure S2: Representative banana samples at the rooting phase, Figure S3: Representative banana samples at the acclimatization phase II (APII), Figure S4: Dwarf plants from Plantation 2 in APII, Figure S5: Representative normal (left) and dwarf (right) plants from Plantation 2 in APII. Photos are in the same size scale, Figure S6: Normal plants from Plantation 1 and M1 meristems in APII, Figure S7: Dwarf plants from Plantation 1 and M1 meristems in APII.

Author Contributions: F.P.C. performed sample collection and processing, data matrix construction, data analysis and writing of results; C.N. developed the project and contributed to the experiment design, analyzed and interpreted the data, elaborated the discussion and reviewed the entire text; M.G.M.-Z. contributed in the methodology and results; J.A.G. performed the in vitro and greenhouse culture work; O.R.-B. contributed and reviewed the statistical part of the experiment; J.M.C.-C. analyzed data, reviewed the manuscript and approved the submission. All authors have read and agreed to the published version of the manuscript.

Funding: This work was mainly financed through the REDU (Ecuador) Project (2017) "Indicadores metabolómicos de variación somaclonal en banano (Musa AAA) y expresión de genes implicados". Further funding was provided by VLIR-UOS through grant "VLIR Network Ecuador".

Institutional Review Board Statement: Not applicable.

Informed Consent Statement: Not applicable.

Data Availability Statement: The datasets analyzed during the current study are available from the corresponding author on reasonable request.

Acknowledgments: We acknowledge the Prometeo Program (SENESCYT, Ecuador), which financed C. Noceda to finally get a collection of somaclonal variants of banana, from which some biological material was taken. Such collection was developed and maintained within the framework of the research projects "Caracterización de alteraciones (epi)genéticas y cromosómicas que originan variación somaclonal durante propagación in vitro de cultivos de alto interés agrícola" (2015) and "Aplicación de técnicas de secuenciación masiva para la caracterización de alteraciones genómicas de variantes somaclonales de banano cv. Williams generadas mediante multiplicación de microtallos" (2015), financed, respectively, by UNEMI and ESPOL (Ecuador), universities to which we would like to acknowledge. We also wish to thank the BIOALI-CYTED network for facilitating the interaction between authors. Likewise, we are grateful to SEBIOCA technicians for their collaboration in identifying dwarf plants in the greenhouse phase and sucker-derived small plants. Our special thanks are given to the Director, administrative staff and analysts of the Phytopathology and Bioproducts laboratories of CIBE-ESPOL.

Conflicts of Interest: The authors declare no conflict of interest.

\section{References}

1. Jain, S.M.; Priyadarshan, P.M. Breeding Plantation Tree Crops: Tropical Species; Springer: Berlin/Heidelberg, Germany, 2009.

2. Dale, J.; James, A.; Paul, J.-Y.; Khanna, H.; Smith, M.; Peraza-Echeverria, S.; Garcia-Bastidas, F.; Kema, G.; Waterhouse, P.; Mengersen, K.; et al. Transgenic Cavendish bananas with resistance to Fusarium wilt tropical race 4. Nat. Commun. 2017, 8, 1-8. [CrossRef]

3. Hamill, S. Processes, costs and traits of plants produced in tissue culture must be considered to develop effective crop production systems. Acta Hortic. 2016, 1113, 85-92. [CrossRef]

4. Govindaraju, S.; Arulselvi, P.I. Effect of cytokinin combined elicitors (L-phenylalanine, salicylic acid and chitosan) on in vitro propagation, secondary metabolites and molecular characterization of medicinal herb-Coleus aromaticus Benth (L). J. Saudi Soc. Agric. Sci. 2018, 17, 435-444. [CrossRef]

5. Valledor, L.; Hasbun, R.; Meijón, M.; Rodríguez, J.L.; Santamaría, E.; Viejo, M.; Berdasco, M.; Feito, I.; Fraga, M.F.; Canal, M.J.; et al. Involvement of DNA methylation in tree development and micropropagation. Plant Cell Tissue Organ Cult. (PCTOC) 2007, 91, 75-86. [CrossRef]

6. Sahijram, L.; Soneji, J.R.; Bollamma, K.T. Analyzing somaclonal variation in micropropagated bananas (Musa spp.). Vitr. Cell. Dev. Biol. Anim. 2003, 39, 551-556. [CrossRef] 
7. Abdellatif, K.F.; Hegazy, A.E.; Aboshama, H.M.; Emara, H.A.; El-Shahed, A.A. Morphological and molecular characterization of somaclonal variations in tissue culture-derived banana plants. J. Genet. Eng. Biotechnol. 2012, 10, 47-53. [CrossRef]

8. Israeli, Y.; Reuveni, O.; Lahav, E. Qualitative aspects of somaclonal variations in banana propagated by in vitro techniques. Sci. Hortic. 1991, 48, 71-88. [CrossRef]

9. Jain, S.M. Tissue culture-derived variation in crop improvement. Euphytica 2001, 118, 153-166. [CrossRef]

10. Bairu, M.W.; Fennell, C.W.; Van Staden, J. The effect of plant growth regulators on somaclonal variation in Cavendish banana (Musa AAA cv. 'Zelig'). Sci. Hortic. 2006, 108, 347-351. [CrossRef]

11. Côte, F.X.; Sandoval-Fernández, J.A.; Marie, P.; Erik, A. Variations in micropropagated bananas and plantains: Literature survey. Fruits 1993, 48, 15-23.

12. De Langhe, E.; Vrydaghs, L.; de Maret, P.; Perrier, X.; Denham, T. Why Bananas Matter: An introduction to the history of banana domestication. Ethnobot. Res. Appl. 2009, 7, 165-177. [CrossRef]

13. Hřibová, E.; Čížková, J.; Christelová, P.; Taudien, S.; De Langhe, E.; Doležel, J. The ITS1-5.8S-ITS2 sequence region in the musaceae: Structure, diversity and use in molecular phylogeny. PLoS ONE 2011, 6, e17863. [CrossRef]

14. Hapsari, L.; Azrianingsih, R.; Arumingtyas, E.L. Genetic variability and relationship of banana cultivars (musa 1.) from East Java, Indonesia based on the internal transcribed spacer region nrdna sequences. J. Trop. Biol. Conserv. 2018, 15, 101-120.

15. Cote, F.; Sandoval-Fernández, J.A.; Marie, P.; Erik, A. Phenotypic variation in micropropagated bananas and plantains. Variación fenotípica de bananos y plátanos micropropagados. CORBANA 1998, 23, 177-198.

16. Sheidai, M.; Aminpoor, H.; Noormohammadi, Z.; Farahani, F. RAPD analysis of somaclonal variation in banana (Musa acuminate L.) cultivar Valery. Acta Biol. Szeged. 2008, 52, 307-311.

17. Choudhary, D.; Kajla, S.; Poonia, A.K.; Brar, B.; Surekha; Duhan, J.S. Molecular assessment of genetic stability using ISSR and RAPD markers in in vitro multiplied copies of commercial banana cv. Robusta. Indian J. Biotechnol. 2015, 14, 420-424.

18. Khatab, I.; Youssef, M. Micropropagation and Assessment of Genetic Stability of Musa sp. cv. Williams using RAPD and SRAP Markers. Egypt. J. Bot. 2018, 58, 371-380. [CrossRef]

19. Noceda, C.; Vargas, A.; Roels, S.; Cejas, I.; Santamaría, E.; Escalona, M.; DeBergh, P.; Rodríguez, R.; Sandoval, J.; Canal, M.J.; et al. Field performance and (epi)genetic profile of plantain (Musa AAB) clone 'CEMSA $\frac{3}{4}$ ' plants micropropagated by temporary immersion systems. Sci. Hortic. 2012, 146, 65-75. [CrossRef]

20. Ray, T.; Dutta, I.; Saha, P.; Das, S.; Roy, S. Genetic stability of three economically important micropropagated banana (Musa spp.) cultivars of lower Indo-Gangetic plains, as assessed by RAPD and ISSR markers. Plant Cell Tissue Organ Cult. (PCTOC) 2006, 85, 11-21. [CrossRef]

21. Aremu, A.O.; Plačková, L.; Bairu, M.W.; Novák, O.; Szüčová, L.; Doležal, K.; Finnie, J.F.; Van Staden, J. Endogenous cytokinin profiles of tissue-cultured and acclimatized 'Williams' bananas subjected to different aromatic cytokinin treatments. Plant Sci. 2014, 214, 88-98. [CrossRef] [PubMed]

22. Dhanapal, S.; Sathish, D.; Satheesh, P.M. Efficiency of Rapd, Ssr and Issr Markers in Evaluating the Genetic Fidelity for Micropropogated Musa Accuminata Plant Exposed To Coal Extracted Humic Acid and Commercially Available Products. Int. J. Agric. Sci. Res. 2014, 4, 77-86.

23. Nandhakumar, N.; Kumar, K.; Sudhakar, D.; Soorianathasundaram, K. Plant regeneration, developmental pattern and genetic fidelity of somatic embryogenesis derived Musa spp. J. Genet. Eng. Biotechnol. 2018, 16, 587-598. [CrossRef] [PubMed]

24. Harrison, B.R.; Wang, L.; Gajda, E.; Hoffman, E.V.; Chung, B.Y.; Pletcher, S.D.; Raftery, D.; Promislow, D.E.L. The metabolome as a link in the genotype-phenotype map for peroxide resistance in the fruit fly, Drosophila melanogaster. BMC Genom. 2020, $21,341$. [CrossRef] [PubMed]

25. Cevallos-Cevallos, J.M.; Reyes-De-Corcuera, J.I.; Etxeberria, E.; Danyluk, M.D.; Rodrick, G.E. Metabolomic analysis in food science: A review. Trends Food Sci. Technol. 2009, 20, 557-566. [CrossRef]

26. Cevallos-Cevallos, J.M.; García-Torres, R.; Etxeberria, E.; Reyes-De-Corcuera, J.I. GC-MS Analysis of Headspace and Liquid Extracts for Metabolomic Differentiation of Citrus Huanglongbing and Zinc Deficiency in Leaves of 'Valencia' Sweet Orange from Commercial Groves. Phytochem. Anal. 2010, 22, 236-246. [CrossRef] [PubMed]

27. Mais, E.; Alolga, R.N.; Wang, S.-L.; Linus, L.O.; Yin, X.; Qi, L.-W. A comparative UPLC-Q/TOF-MS-based metabolomics approach for distinguishing Zingiber officinale Roscoe of two geographical origins. Food Chem. 2018, 240, 239-244. [CrossRef]

28. Nam, K.-H.; Kim, Y.-J.; Moon, Y.S.; Pack, I.-S.; Kim, C.-G. Salinity affects metabolomic profiles of different trophic levels in a food chain. Sci. Total. Environ. 2017, 599-600, 198-206. [CrossRef]

29. Mohandas, S.; Ravishankar, K.V. Banana: Genomics and Transgenic Approaches for Genetic Improvement; Springer: Berlin/Heidelberg, Germany, 2016; pp. 1-346. [CrossRef]

30. Abdelrahman, M.; Burritt, D.J.; Tran, L.-S.P.; Adbelrahman, M. The use of metabolomic quantitative trait locus mapping and osmotic adjustment traits for the improvement of crop yields under environmental stresses. Semin. Cell Dev. Biol. 2018, 83, 86-94. [CrossRef] [PubMed]

31. Hong, J.; Yang, L.; Zhang, D.; Shi, J. Plant Metabolomics: An Indispensable System Biology Tool for Plant Science. Int. J. Mol. Sci. 2016, 17, 767. [CrossRef]

32. Cevallos-Cevallos, J.M.; Jines, C.; Maridueña-Zavala, M.G.; Molina-Miranda, M.J.; Ochoa, D.E.; Flores-Cedeno, J.A. GC-MS metabolite profiling for specific detection of dwarf somaclonal variation in banana plants. Appl. Plant Sci. 2018, 6, e01194. [CrossRef] [PubMed] 
33. Murashige, T.; Skoog, F. A Revised Medium for Rapid Growth and Bio Assays with Tobacco Tissue Cultures. Physiol. Plant. 1962, 15, 473-497. [CrossRef]

34. Vuylsteke, D.R. Shoot-Tip Culture for the Propagation, Conservation and Exchange of Musa Germplasm; International Institute of Tropical Agriculture: Ibadan, Nigeria, 1989.

35. Maridueña-Zavala, M.G.; Freire-Peñaherrera, A.; Cevallos-Cevallos, J.M.; Peralta, E.L. GC-MS metabolite profiling of Phytophthora infestans resistant to metalaxyl. Eur. J. Plant Pathol. 2017, 149, 563-574. [CrossRef]

36. Pluskal, T.; Castillo, S.; Villar-Briones, A.; Orešič, M. MZmine 2: Modular framework for processing, visualizing, and analyzing mass spectrometry-based molecular profile data. BMC Bioinform. 2010, 11, 395. [CrossRef] [PubMed]

37. Neumann, G.; Römheld, V. Root excretion of carboxylic acids and protons in phosphorus-deficient plants. Plant Soil 1999, 211, 121-130. [CrossRef]

38. Aguiar, N.O.; Olivares, F.L.; Novotny, E.H.; Canellas, L.P. Changes in metabolic profiling of sugarcane leaves induced by endophytic diazotrophic bacteria and humic acids. PeerJ 2018, 6, e5445. [CrossRef] [PubMed]

39. Li, P.; Wang, A.; Du, W.; Mao, L.; Wei, Z.; Wang, S.; Yuan, H.; Ji, R.; Zhao, L. Insight into the interaction between Fe-based nanomaterials and maize (Zea mays) plants at metabolic level. Sci. Total Environ. 2020, 738, 139795. [CrossRef]

40. Stephens, C.; Christen, B.; Fuchs, T.; Sundaram, V.; Watanabe, K.; Jenal, U. Genetic Analysis of a Novel Pathway for d-Xylose Metabolism in Caulobacter crescentus. J. Bacteriol. 2006, 189, 2181-2185. [CrossRef]

41. Klalvraa, S.; Gregersen, N. In vitro studies on the oxidation of medium-chain dicarboxylic acids in rat liver. ScienceDirect 1986, $876,515-525$.

42. Krishna, H.; Alizadeh, M.; Singh, D.; Singh, U.; Chauhan, N.; Eftekhari, M.; Sadh, R.K. Somaclonal variations and their applications in horticultural crops improvement. 3 Biotech 2016, 6, 1-18. [CrossRef]

43. Riggs, J.W.; Rockwell, N.C.; Cavales, P.C.; Callis, J. Identification of the plant ribokinase and discovery of a role for Arabidopsis Ribokinase in nucleoside metabolism. J. Biol. Chem. 2016, 291, 22572-22582. [CrossRef] [PubMed]

44. Ishida, Y.; Kakibuchi, K.; Kudo, R.; Izumori, K.; Tajima, S.; Akimitsu, K.; Tanaka, K. Effects of rare sugars on growth and disease occurrence in head lettuce. Acta Hortic. 2012, 927, 929-934. [CrossRef]

45. Vázquez, A.M.; Linacero, R. Stress and Somaclonal Variation. In Plant Developmental Biology_Biotechnological Perspectives; Springer International Publishing: Berlin/Heidelberg, Germany, 2010; Volume 2, pp. 45-64.

46. Hossain, A.; Yamaguchi, F.; Matsuo, T.; Tsukamoto, I.; Toyoda, Y.; Ogawa, M.; Nagata, Y.; Tokuda, M. Rare sugar d-allulose: Potential role and therapeutic monitoring in maintaining obesity and type 2 diabetes mellitus. Pharmacol. Ther. 2015, 155, 49-59. [CrossRef]

47. Ciereszko, I. Regulatory roles of sugars in plant growth and development. Acta Soc. Bot. Pol. 2018, 87, 1-13. [CrossRef]

48. Mazelis, M. Amino Acid Catabolism. In Amino Acids and Derivatives; Academic Press: Cambridge, MA, USA, $1980 ;$ pp. 541-567.

49. Sassaki, G.L.; de Souza, L.M. Mass Spectrometry Strategies for Structural Analysis of Carbohydrates and Glycoconjugates. In Tandem Mass Spectrometry-Molecular Characterization; InTech: London, UK, 2013.

50. Scheller, H.V.; Ulvskov, P. Hemicelluloses. Annu. Rev. Plant Biol. 2010, 61, 263-289. [CrossRef]

51. Buchanan, B.B.; Gruissem, W.; Jones, R.L. Biochemistry and Molecular Biology of Plants; John Wiley \& Sons: Hoboken, NY, USA, 2000.

52. Cohen, E.; Merzendorfer, H. Biologically-Inspired Systems Extracellular Sugar-Based Biopolymers Matrices. Available online: http:/ / www.springer.com/series / 8430 (accessed on 21 January 2021).

53. Mathews, C.K.; Holde, K.E.; Appling, D.R. Biochemistry; Pearson: London, UK, 2013.

54. Bindschedler, L.V.; Tuerck, J.; Maunders, M.; Ruel, K.; Petit-Conil, M.; Danoun, S.; Boudet, A.-M.; Joseleau, J.-P.; Bolwell, G.P. Modification of hemicellulose content by antisense down-regulation of UDP-glucuronate decarboxylase in tobacco and its consequences for cellulose extractability. Phytochemistry 2007, 68, 2635-2648. [CrossRef] [PubMed]

55. Yang, Y.; Kang, L.; Wu, R.; Chen, Y.; Lu, C. Genome-wide identification and characterization of UDP-glucose dehydrogenase family genes in moso bamboo and functional analysis of PeUGDH4 in hemicellulose synthesis. Sci. Rep. 2020, 10, 1-13. [CrossRef] [PubMed]

56. Xiao, C.; Anderson, C.T. Roles of pectin in biomass yield and processing for biofuels. Front. Plant Sci. 2013, 4, 67. [CrossRef] [PubMed]

57. Cosgrove, D.J. Growth of the plant cell wall. Nat. Rev. Mol. Cell Biol. 2005, 6, 850-861. [CrossRef]

58. Karp, A. Mechanisms of Somaclonal Variation. Biotechnol. Biotechnol. Equip. 1993, 7, 20-25. [CrossRef]

59. Mathur, J. Cell shape development in plants. Trends Plant Sci. 2004, 9, 583-590. [CrossRef]

60. Vogt, T. Phenylpropanoid Biosynthesis. Mol. Plant 2010, 3, 2-20. [CrossRef]

61. Bais, H.P.; Vepachedu, R.; Gilroy, S.; Callaway, R.M.; Vivanco, J.M. Allelopathy and Exotic Plant Invasion: From Molecules and Genes to Species Interactions. Science 2003, 301, 1377-1380. [CrossRef]

62. He, M.; He, C.-Q.; Ding, N.-Z. Abiotic Stresses: General Defenses of Land Plants and Chances for Engineering Multistress Tolerance. Front. Plant Sci. 2018, 9, 1771. [CrossRef]

63. Masclaux-Daubresse, C.; Reisdorf-Cren, M.; Pageau, K.; Lelandais, M.; Grandjean, O.; Kronenberger, J.; Valadier, M.H.; Feraud, M.; Jouglet, T.; Suzuki, A. Glutamine synthetase-glutamate synthase pathway and glutamate dehydrogenase play distinct roles in the sink-source nitrogen cycle in tobacco. Plant Physiol. 2006, 140, 444-456. [CrossRef] 
64. Van Hengel, A.J.; Tadesse, Z.; Immerzeel, P.; Schols, H.; Van Kammen, A.; De Vries, S.C. N-Acetylglucosamine and GlucosamineContaining Arabinogalactan Proteins Control Somatic Embryogenesis. Plant Physiol. 2001, 125, 1880-1890. [CrossRef] [PubMed]

65. Yang, T.; Echols, M.; Martin, A.; Bar-Peled, M. Identification and characterization of a strict and a promiscuous Nacetylglucosamine-1-P uridylyltransferase in Arabidopsis. Biochem. J. 2010, 430, 275-284. [CrossRef]

66. Bull, A.T. Chemical Composition of Wild-type and Mutant Aspergillus nidulans Cell Walls. The Nature of Polysaccharide and Melanin Constituents. J. Gen. Microbiol. 1970, 63, 75-94. [CrossRef]

67. Freeze, H.H.; Lomis, W. Isolation and Characterization of a Component of the Surface Sheath of Dictyostelium discoideum. J. Biol. Chem. 1977, 10, 820-824. [CrossRef]

68. Niemetz, R.; Karcher, U.; Kandler, O.; Tindall, B.J.; Konig, H. The cell wall polymer of the extremely halophilic archaeon Natronococcus occultus. JBIC J. Biol. Inorg. Chem. 1997, 249, 905-911. [CrossRef] [PubMed]

69. Vroh-Bi, I.; Anagbogu, C.; Nnadi, S.; Tenkouano, A. Genomic characterization of natural and somaclonal variations in bananas (Musa spp.). Plant Mol. Biol. Rep. 2011, 29, 440-448. [CrossRef] 